Benha Veterinary Medical Journal 38 (2020) 106-111

Benha Veterinary Medical Journal
$\begin{gathered}\text { Official Journal Issued by } \\ \text { Fecterly of } \\ \text { Veterinary Medicine }\end{gathered}$
Journal homepage: https://bvmj.journals.ekb.eg/

Original Paper

\title{
Molecular detection of virulence factors in some food poisoning bacteria isolated from chicken meat and giblet
}

Saad M. Saad', Hemmat M. Ibrahim', Mohamed A. Hassan', Suhair N. Shehab Eldin²,*

${ }^{I}$ Food Hygiene and Control Dept., Fac. Vet. Med., Benha University

${ }^{2}$ Veterinarian, Directorate of Veterinary Medicine, Qalubiya Governorate

\begin{tabular}{|c|c|}
\hline ARTICLE INFO & ABSTRACT \\
\hline $\begin{array}{l}\text { Keywords } \\
\text { Chicken meat and giblet } \\
\text { E. coli } \\
\text { PCR } \\
\text { S. typhi } \\
\text { Staph. aureus } \\
\text { Y. enterocolitica } \\
\text { Received 26/05/2020 } \\
\text { Accepted 30/06/2020 } \\
\text { Availa6le On-Line } \\
\text { 08/09/2020 }\end{array}$ & $\begin{array}{l}\text { Many bacterial detection rapid methods developed including nucleic acid-based analysis which } \\
\text { considered the most precise, sensitive, and famous method of detection. This study aimed to } \\
\text { investigate the bacterial hygienic quality of some chicken meat and giblet with special concern } \\
\text { of molecular detection of some virulence factors associated with some isolated food poisoning } \\
\text { bacteria. E. coli, Salmonella, S. aureus, and } Y \text {. enterocolitica strains were isolated from } \\
\text { commercial and home-reared chicken meat and giblet in Menoufiya Governorate, Egypt. } \\
\text { Accurately, stx } 1 \text {, stx } 2 \text {, eaeA, and hylA genes were detected in } 45.4,63.6,18.1 \text {, and } 27.2 \% \text { of } \\
\text { the isolated E. coli strains, respectively. invA, hilA, and fimH genes were detected in } 100,71.4 \text {, } \\
\text { and } 85.7 \% \text { of the examined Salmonella isolates, respectively. Regarding to the examined } Y \text {. } \\
\text { enterocolitica isolates, Inv gene was detected lonely in } 25 \% \text {, while it was mixed with ystA gene } \\
\text { in } 75 \% \text { of the examined isolates. Detection of enterotoxigenic Staph. aureus genes revealed } \\
\text { detection of staphylococcal enterotoxins genes types SEA, and SEB genes in } 20 \text {, and } 10 \% \text {; } \\
\text { moreover, mixed SEA+SED, SEB+SEC producing genes were detected in } 10 \% \text { for each, } \\
\text { respectively. The present results proved that PCR assay is helpful, rapid and accurate detection } \\
\text { method. Strict hygienic measures during slaughtering and handling of chicken meat and giblet } \\
\text { must be followed. }\end{array}$ \\
\hline
\end{tabular}

\section{INTRODUCTION}

Chicken is one of the domesticated birds reared for their meat consumption. Chicken meat is a good source of prime quality protein; but unfortunately, it may acquire several foodborne pathogens during different processing treatment. It is recorded that when it is contaminated, it can cause foodborne illness to the human consumers (Bhandari et al., 2013).

Live birds had been infected with unique microorganisms on their feathers, skin and intestinal tract. For this reason, the infection of chicken meat and giblet starts from the time of slaughtering, defeathering, evisceration, until the very last product storage and distribution (Capita et al., 2004). Poultry are recognized to harbor a big range of bacteria that are pathogenic to human being.

Enterobacteriacae, especially $E$. coli and Salmonella considered important food poisoning organisms; besides being involved as an indicator for possible fecal contamination (Synge, 2000). Their accumulation in poultry cuts and its products indicates lack of proper sanitation.

In recent years, E. coli, Salmonella, and Staph. aureus have become recorded as a serious foodborne pathogens and has been associated with numerous foodborne outbreaks, where $E$. coli includes a variety of different types that range from virulent commensal strains to highly pathogenic strains that cause variable degrees of infections in both humans and animals (Kaper et al., 2004); namely, enteropathogenic $E$. coli, enterotoxigenic E. coli, enterohemorrhagic E. coli, enteroinvasive $E$. coli, and enteroaggregative $E$. coli (Gomez-Duarte, 2013). Shiga toxin-producing E. coli
(STEC) can lead to sporadic cases and outbreaks that can cause several illnesses, such as hemolytic colitis (HC) and hemolytic uremic syndrome (HUS), following the onset of diarrhea.

In addition, Salmonella was contributed among the causes of worldwide foodborne pathogens. According to an estimation made in 2010, Salmonellae were involved in more than 80 million cases of foodborne gastroenteritis every year worldwide, of which 155,000 were fatal (Majowicz et al., 2010).

Regarding to Staph. aureus, recorded by Normanno et al. (2007) as the most pathogenic species of Staphylococci that is considered the $3^{\text {rd }}$ most foodborne disease causing in the world, which essentially referred to its wide variety of enterotoxins production named Staphylococcal enterotoxins. Traditional most frequent SEs were recorded to be SEA to SEE; in addition, SEG to SEI, SER to SET may be detected with demonstrated emetic activity and gastrointestinal troubles.

Bolton et al. (2013) said that yersiniosis is a gastrointestinal infection caused by $Y$. enterocolitica which is considered the most prevalent gastrointestinal infection after Campylobacteriosis and salmonellosis in the industrial countries. It was estimated that $Y$. enterocolitica causes about 117,000 infected cases, 640 hospitalizations, and 35 deaths in the USA/year (CDC, 2019).

Ingestion of such foodborne pathogens is mainly incriminated in many food poisoning symptoms including gastroenteritis and sometimes systemic infections. The initial symptoms are dramatic diarrhea, which is sometimes accompanied by abdominal pain, nausea, vomiting, 
headaches, chills, myalgia and variable-grades of fever (Ziprin and Hume, 2001). Detection of foodborne pathogens basing on traditional identification of microorganisms by their biochemical, morphological and immunological characteristics using selective culture media are time consuming and possibility of errors can occur in enumeration and sampling when microorganism present in low number in the sample. So, Methods based on nucleic acid detection, PCR (Polymerase Chain Reaction), identified as a powerful diagnostic method for the detection of pathogenic microorganisms; these techniques are specific, rapid, and sensitive in detection and identification of organisms comparing with other methods (Wang et al., 2007). Therefore, this study aimed to molecular detection of some virulence factors associated with some isolated food poisoning bacteria.

\section{MATERIAL AND METHODS}

\subsection{Collection of samples}

A total of forty bacterial isolates represented by $11 \mathrm{E}$. coli represented by serotypes $\left(\mathrm{O}_{2}: \mathrm{H}_{6}, \mathrm{O}_{26}: \mathrm{H}_{11}, \mathrm{O}_{55}: \mathrm{H}_{7}, \mathrm{O}_{78}\right.$, $\mathrm{O}_{91}: \mathrm{H}_{21}, \mathrm{O}_{111}: \mathrm{H}_{2}, \mathrm{O}_{119}: \mathrm{H}_{6}, \mathrm{O}_{124}, \mathrm{O}_{128}: \mathrm{H}_{2} \mathrm{O}_{153}: \mathrm{H}_{2}$ and $\left.\mathrm{O}_{158}\right)$ strains, 7 Salmonella represented by $(S$. Enteritidis, $S$. Kentucky, S. Larochelle, S. Molade, S. Papuana, S. Takoradi and $S$. Typhimurium serotypes), $12 Y$. enterocolitica, and 10
Staph. aureus isolates were investigated. Such pathogenic strains were isolated from different fresh chicken meat and giblet collected from home-reared (of 45 days old) and commercial chicken carcasses in Menoufiya governorate, Egypt; during the period of January to December 2018 and kept at $-18^{\circ} \mathrm{C}$ until molecular examination for detection of some virulence factors associated with them was performed. 2.2. The strains under examination were isolated according to:

- ISO 16649-2 (2001) for detection and isolation of E. coli; which were serologically identified according to Kok et al. (1996).

- ISO 6579 (2017) for isolation and identification of Salmonellae; which were serologically identified according to Kauffman - White scheme (Kauffman, 1974).

- ISO (6888-1:1999, A1:2003) for detection and isolation of S. aureus.

- ISO 10273 (2017) for detection of Yersinia enterocolitica.

2.3. Primer sequences of $E$. coli, Salmonella, $Y$. enterocolitica, and Staph. aureus virulence genes used for PCR identification system as follow in Tables (1 to 4). $E$. coli was examined for the presence of stxl, stx2, eaeA and hylA genes; while, Salmonellae were examined for the presence of invA, hila and fimH genes; furthermore, Staph. aureus was examined for the presence of SEs (A to D). Finally, $Y$. enterocolitica was examined for the presence of inv and $y s t A$ genes.

Table 1 Primer sequences of $E$. coli genes used for PCR identification system.

\begin{tabular}{|c|c|c|c|}
\hline Target gene & Oligonucleotide sequence $\left(5^{\prime} \rightarrow 3^{\prime}\right)$ & Product size (bp) & References \\
\hline stxl (F) & 5' ACACTGGATGATCTCAGTGG '3 & \multirow{2}{*}{614} & \multirow{4}{*}{ Dhanashree and Mallya (2008) } \\
\hline $\operatorname{Stxl}(\mathrm{R})$ & 5' CTGAATCCCCCTCCATTATG '3 & & \\
\hline Stx2 (F) & 5' CCATGACAACGGACAGCAGTT ' 3 & \multirow{2}{*}{779} & \\
\hline Stx2 (R) & 5' CCTGTCAACTGAGCAGCACTTTG ' 3 & & \\
\hline$e a e A(\mathrm{~F})$ & 5' GTGGCGAATACTGGCGAGACT ' 3 & \multirow{2}{*}{890} & \multirow{2}{*}{ Mazaheri et al. (2014) } \\
\hline$e a e A(\mathrm{R})$ & 5' CCCCATTCTTTTTCACCGTCG '3 & & \\
\hline hylA (F) & 5' ACGATGTGGTTTATTCTGGA ' 3 & \multirow{2}{*}{165} & \multirow{2}{*}{ Fratamico et al. (1995) } \\
\hline hylA (R) & 5' CTTCACGTGACCATACATAT ' 3 & & \\
\hline
\end{tabular}

$\underline{\text { Table } 2 \text { Primer sequences of Salmonellae genes used for PCR system }}$

\begin{tabular}{|c|c|c|c|c|}
\hline Target gene & Oligonucleotide sequence $\left(5^{\prime} \rightarrow 3^{\prime}\right)$ & Product size (bp) & \multicolumn{2}{|c|}{ References } \\
\hline $\operatorname{invA}(\mathrm{F})$ & 5' GTGAAATTATCGCCACGTTCGGGCA '3 & \multirow{2}{*}{284} & \multirow{2}{*}{\multicolumn{2}{|c|}{ Shanmugasamy et al. (2011 }} \\
\hline $\operatorname{invA}(\mathrm{R})$ & 5' TCATCGCACCGTCAAAGGAACC ' 3 & & & \\
\hline hilA $(\mathrm{F})$ & 5' CTGCCGCAGTGTTAAGGATA '3 & \multirow{2}{*}{497} & \multirow{2}{*}{ Guo et al. } & \multirow{2}{*}{$(2000)$} \\
\hline hilA (R) & 5' CTGTCGCCTTAATCGCATGT '3 & & & \\
\hline $\operatorname{fimH}(\mathrm{F})$ & 5' GGA TCC ATG AAA ATA TAC TC ' 3 & \multirow{2}{*}{1008} & \multirow{2}{*}{ Menghistu } & \multirow{2}{*}{ (2010) } \\
\hline fim $H(\mathrm{R})$ & 5' AAG CTT TTA ATC ATA ATC GAC TC 3 & & & \\
\hline
\end{tabular}

Table 3 Primer sequences of enterotoxin genes of Staph. aureus

\begin{tabular}{|c|c|c|c|}
\hline Target gene & Oligonucleotide sequence $\left(5^{\prime} \rightarrow 3^{\prime}\right)$ & Product size (bp) & References \\
\hline sea $(\mathrm{F})$ & 5' TTGGAAACGGTTAAAACGAA'3 & \multirow{2}{*}{120} & \multirow{8}{*}{ Rall et al. (2008) } \\
\hline sea $(\mathrm{R})$ & 5' GAACCTTCCCATCAAAAACA ' 3 & & \\
\hline $\operatorname{seb}(\mathrm{F})$ & 5' TCGCATCAAACTGACAAACG ' 3 & \multirow{2}{*}{478} & \\
\hline $\operatorname{seb}(\mathrm{R})$ & 5' GCGGTACTCTATAAGTGCC ' 3 & & \\
\hline $\sec (\mathrm{F})$ & 5' GACATAAAAGCTAGGAATTT ' 3 & \multirow{2}{*}{257} & \\
\hline $\sec (\mathrm{R})$ & 5' AAATCGGATTAACATTATCC ' 3 & & \\
\hline $\operatorname{sed}(\mathrm{F})$ & 5' CTAGTTTGGTAATATCTCCT ' 3 & \multirow{2}{*}{317} & \\
\hline $\operatorname{sed}(\mathrm{R})$ & 5' TAATGCTATATCTTATAGGG ' 3 & & \\
\hline
\end{tabular}

\begin{tabular}{|c|c|c|c|c|}
\hline Target gene & Primers & Oligonucleotide sequence $\left(5^{\prime} \rightarrow 3^{\prime}\right)$ & Product size (bp) & References \\
\hline \multirow{2}{*}{$i n v$} & $\mathrm{YC} 1(\mathrm{~F})$ & 5'CTGTGGGGAGAGTGGGGAAGTTTGG'3 & \multirow{2}{*}{570} & \multirow{2}{*}{ Rasmussen et al. (1994) } \\
\hline & $\mathrm{YC} 2(\mathrm{R})$ & 5'GAACTGCTTGAATCCCTGAAAACCG ' 3 & & \\
\hline \multirow{2}{*}{ ysta } & $\operatorname{Pr} 2 \mathrm{a}(\mathrm{F})$ & 5' AATGCTGTCTTCATTTGGAGCA '3 & \multirow{2}{*}{145} & \multirow{2}{*}{ Ibrahim et al. (1997) } \\
\hline & $\operatorname{Pr} 2 c(R)$ & 5' ATCCCAATCACTACTGACTTC ' 3 & & \\
\hline
\end{tabular}


2.4. DNA preparation from bacterial culture was performed according to Shah et al. (2009).

2.5. DNA amplification:

2.5.1. Amplification reaction of E. coli was performed according to Fagan et al. (1999).

2.5.2. Amplification of virulence genes of Salmonellae was performed according to Singh et al. (2013).

2.5.3. Amplification reaction of inv and ystA genes of $Y$. enterocolitica was performed according to Momtaz et al. (2013).

2.5.4. Amplification of enterotoxin genes of Staph. aureus was performed according to Mehrotra et al. (2000).

\section{RESULTS}

Table (5) showed the occurrence of virulence genes of Shiga-toxin producing E. coli strains where, STX1, STX2, $e a e A$, and hylA genes were detected in 45.4, 63.6, 18.1, and $27.2 \%$ of the examined strains, respectively. Fig. (1) showed the agarose gel electrophoresis bands proving the detection of STX1 gene in E. coli $\mathrm{O}_{78}, \mathrm{O}_{128}$ and $\mathrm{O}_{158}$ as shown in lanes $(4,9$, and 11$)$, respectively; lanes $(1,3$, and 10$)$ representing E. coli $\mathrm{O}_{2}, \mathrm{O}_{55}$ and $\mathrm{O}_{153}$ as positive E. coli for $S T X 2$ gene; lane (7) representing E. coli $\mathrm{O}_{119}$ as positive strain for both STX1 and STX2 genes; lane (5) representing E. coli $\mathrm{O}_{91}$ as positive strain for $S T X 1, S T X 2$, and $h l y A$ genes; lanes (2, and 6) representing E. coli $\mathrm{O}_{26}$, and $\mathrm{O}_{111}$ serotypes as positive for STX1, STX2, eaeA and hlyA genes. Finally, lane (8) representing $E$. coli $\mathrm{O}_{124}$ as negative $E$. coli strain for all $S T X 1, S T X 2$, eaeA and hlyA genes. Table (6) presented the incidence of the examined virulence genes in Salmonellae isolates, where hilA, and fimH genes were detected at an incidence of 71.4 , and $85.7 \%$ in the examined isolates, respectively. While, invA was detected in $100 \%$ of examined strains. Moreover, fig. (2) showed the agarose gel electrophoresis results. Lanes $(1,2,4$, and 7$)$ showed that $S$. enteritidis, S. kentuckey, S. molade, and S. typhimurium as positive strains for invA, hilA and fimH genes. Lane (3) showed that $S$. larochelle had both invA and hilA genes. Lanes $(5,6)$ representing $S$. papuana and $S$. takoradi as positive strains for $i n v A$ and fim $H$ genes.

Staphylococcal enterotoxin $\mathrm{A}, \mathrm{B}, \mathrm{A}+\mathrm{D}$, and $\mathrm{B}+\mathrm{C}$ genes were detected in $20,10,10$, and $10 \%$ in five isolates, while $50 \%$ of the examined Staph. aureus isolates showed absence of enterotoxins genes (-ve) as shown in table (7); furthermore, Fig. (3) shows the agarose gel electrophoresis reading proving the results of SEs (SEA, SEB, SEC, and SED) genes in the examined Staph. aureus isolates, where lanes 4 and 9 represented positive Staph. aureus strains for SEA gene; lane 2 as positive Staph. aureus strain for $S E B$ gene; lane 7 as positive Staph. aureus strain for mixed SEA and SED genes; lane 10 as positive Staph. aureus strain for both $S E B$ and $S E C$ genes. Finally, five strains showed absence of enterotoxin genes as non-toxigenic strains as present in lanes $1,3,5,6$, and 8 .

Table 5 Occurrence of virulence genes of Shiga toxin-producing $E$. coli strains isolated from chicken meat and giblets $(\mathrm{n}=11)$

\begin{tabular}{|c|c|c|c|c|}
\hline E. coli Serovars & stxl & stx 2 & eaeA & hylA \\
\hline $\mathrm{O}_{2}: \mathrm{H}_{6}$ & - & + & - & - \\
\hline $\mathrm{O}_{26}: \mathrm{H}_{11}$ & + & + & + & + \\
\hline $\mathrm{O}_{55}: \mathrm{H}_{7}$ & - & + & - & - \\
\hline $\mathrm{O}_{78}$ & + & - & - & - \\
\hline $\mathrm{O}_{91}: \mathrm{H}_{21}$ & + & + & - & + \\
\hline $\mathrm{O}_{111}: \mathrm{H}_{2}$ & + & + & + & + \\
\hline $\mathrm{O}_{119}: \mathrm{H}_{6}$ & + & + & - & - \\
\hline $\mathrm{O}_{124}$ & - & - & - & - \\
\hline $\mathrm{O}_{128}: \mathrm{H}_{2}$ & - & - & - & - \\
\hline $\mathrm{O}_{153}: \mathrm{H}_{2}$ & - & + & - & - \\
\hline $\mathrm{O}_{158}$ & - & - & - & - \\
\hline Total incidence* & 45.4 & 63.6 & 18.1 & 27.2 \\
\hline
\end{tabular}

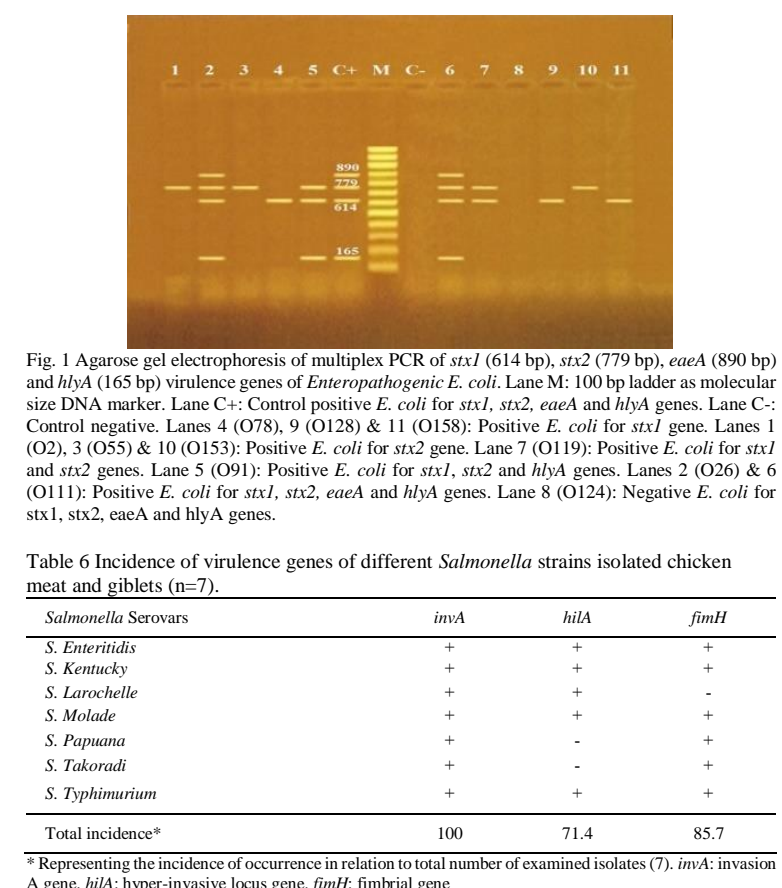

A gene. hilA: hyper-invasive locus gene. fimH: fimbrial gene

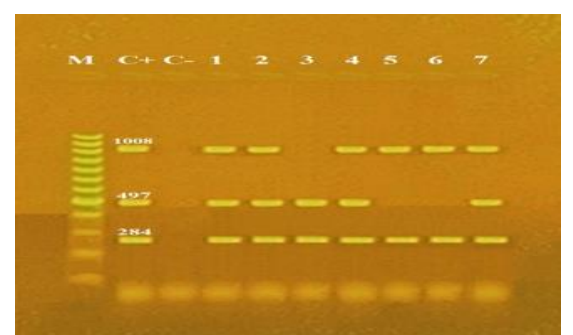

Fig. 2 Agarose gel electrophoresis of multiplex PCR of invA (260 bp), hilA (497 bp) and fimH (1008 bp) virulence genes for characterization of Salmonella strains. Lane M: $100 \mathrm{bp}$ ladder a molecular size DNA marker. Lane C+: Control positive S. Typhimurium for invA, hilA and fimH genes. Lane C-: Control negative. Lanes 1 (S. enteritidis), 2 (S. kentuckey), 4 (S. molade) \& 7 (S. for invA and hilA genes. Lanes 5 (S. papuana) \& 6 (S. takoradi): Positive strains for $i n v A$ and fim for $i n v A$ and hilA genes. Lanes 5 (S. papuana) \& 6 (S. takoradi): Positive strains for $i n v A$ and fimH
genes.

Regarding to inv and ystA genes of $Y$. enterocolitica isolates, Table (8) showed that inv was detected alone in $25 \%$, while it was mixed with $y s t A$ gene in $75 \%$ of the examined isolates. In addition, Fig. (4) showed presence of inv gene bands in lanes 4, 6, and 11; while both inv and ystA genes were detected in lanes $1,2,3,5,7,8,9,10$, and 12 .

Table 7 Occurrence of enterotoxin genes of $S$. aureus strains isolated from chicken meat and giblets ( $\mathrm{n}=15$ strains)

\begin{tabular}{lcc} 
and giblets $(\mathrm{n}=15$ strains $)$ & & \\
\hline S. aureus enterotoxins & No. & $\%$ \\
\hline A & 2 & 20 \\
B & 1 & 10 \\
A+D & 1 & 10 \\
B+C & 1 & 10 \\
$-v e$ & 5 & 50 \\
\hline Total & 10 & 100 \\
\hline
\end{tabular}

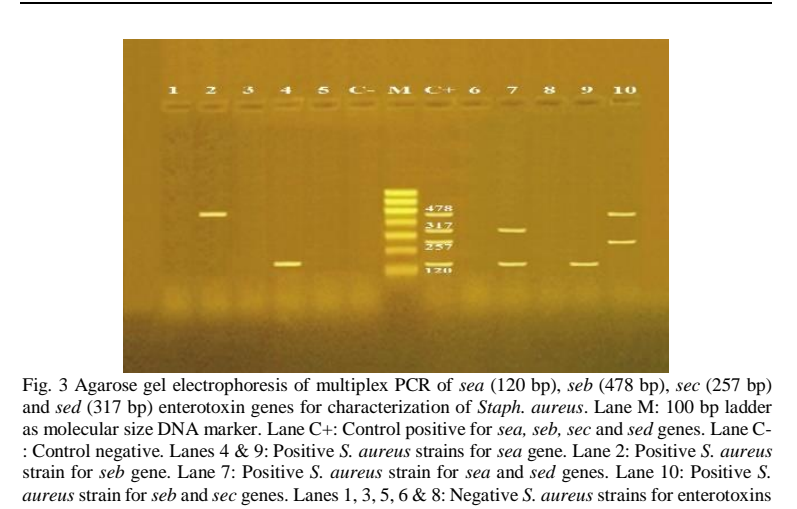


Table 8 Occurrence of virulence genes of $Y$. enterocolitica isolated from chicken meat and giblets $(\mathrm{n}=12)$

\begin{tabular}{lcc}
\hline Virulence genes & No. & $\%$ \\
\hline inv + ystA & 9 & 75 \\
$I n v$ & 3 & 25 \\
\hline Total & 12 & 100 \\
\hline inv: chromosomal invasion gene. $y s t A$ : Yersinia stable toxin gene & &
\end{tabular}

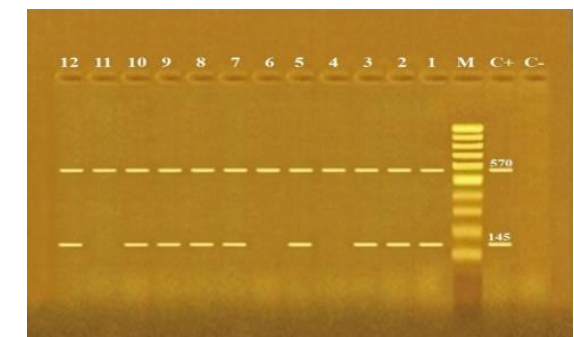

Fig. 4 Agarose gel electrophoresis of multiplex PCR of inv (570 bp) and ystA (145 bp) virulence genes for characterization of $Y$. enterocolitica. Lane M: 100 bp ladder as molecular size DNA marker. Lane C+: Control positive $Y$. enterocolitica for $i n v$ and ystA genes. Lane C-: Contro negative. Lanes 1, 2, 3, 5, 7, 8, 9, 10 \& 12: Positive $Y$. enterocolitica for $i n v$ and $y s t A$ genes. Lane 4,6 \& 11: Positive $Y$. enterocolitica for inv gene.

\section{DISCUSSION}

Chicken meat is a prime source of white meat and protein of high biological value (Shedeed, 1999). Unfortunately, fresh chicken carcasses may host large number of foodborne pathogens from their feathers or the alimentary tract during slaughtering processes including the additional bacterial load from the environment, equipment and operator's hands (Živković, 2001); which predisposing food poisoning especially with bacterial pathogens (Sodha et al., 2009). Therefore, rapid, sensitive, and accurate detectors such as PCR assays were developed (Hassan, 2012). Foodborne Enterobacteriacae bacteria such as E. coli and Salmonella are incriminated in many human diseases causing suppurative lesions, neonatal septicemia and meningitis (Collins et al., 1991). Between 2003 and 2012, 390 E. coli food poisoning outbreaks were encountered in the USA, resulting in 4,928 cases, 1,272 hospitalizations and 33 deaths (Heiman et al., 2015), while CDC (2020) estimated that Salmonella bacteria cause about 1.35 million infections, 26,500 hospitalizations, and 420 deaths in the United States every year, where food of animal origin is the main source for most of these illnesses.

Pathogenic E. coli infectivity is related to several virulence factors, such as intimin (eaeA), hemolysin (hylA), STX1, and STX2; eaeA and hylA genes responsible for the bacterium's adherence to the intestinal mucosa, and lyses erythrocytes, respectively, while $S T X 1$ and $S T X 2$ genes increase the intestinal motility and solution accumulations (Paton and Paton, 1998). These genes were reported to be the main factors associated with $E$. coli food poisoning which may lead to the occurrence of HC and HUS in humans in advanced cases (Sami and Roya, 2007).

Results of molecular detection of $E$. coli virulence genes represented by $S T X 1, S T X 2$, eaeA, and hylA genes in the examined isolates as mentioned in Table (5) and Fig. (1) are in agree with those recorded by Mohamed (2017), Abdallah (2018), Mustafa (2018), and El-Hanafy (2019) who detected E. coli virulence genes in their isolates from raw chicken meat samples.

In addition, several Salmonella specific virulence genes such as invA, hila, and fimH were recorded to take an important role in the pathogenicity have been identified; where in $S$. Typhimurium serovar, at least 80 different virulence genes have been identified (Baumler et al. 2000). Some genes are known to be involved in adhesion and invasion, like fimH
(Duncan et al., 2005), invA (Galan et al., 1992), and other genes associated with toxin production.

Results of the detection of Salmonella virulence genes as mentioned in Table (6) and Fig. (2) were in agree with those recorded by Eissa (2017), Abd El-Halim (2017), Abdallah (2018), and El-Hanafy (2019) who detected different Salmonella virulence genes in their different Salmonella isolates such as $S$. enteritidis, $S$. typhimurium and $S$. Papauna which were isolated from different raw chicken meat products.

Regarding to Staph. aureus enterotoxins genes, Jørgensen et al. (2005) said that Staph. aureus produces many important virulence factors including SEs which were reported in more than $70 \%$ of Staph. aureus isolates. Staphylococcal enterotoxins (SEs) are responsible for diarrhea, vomiting and other symptoms associated with staphylococcal food poisoning.

The present results as demonstrated in table (7) and fig. (3) agreed with those recorded by Ahmed (2016), Abd El-Salam (2018), Gaafar (2018), Naguib (2017), and El-Hanafy (2019) who detected different SEs producing genes in their entero-toxigenic Staph. aureus isolates from raw chicken meat cuts, and chicken meat product samples.

Yersiniosis is an infection caused most often by eating raw or undercooked contaminated meat with $Y$. enterocolitica bacteria. It was estimated that $Y$. enterocolitica causes almost 117,000 illnesses, 640 hospitalizations, and 35 deaths in the United States every year, where children were infected more often than adults, and the infection is more common in the winter (CDC, 2016). Regarding to detection of $Y$. enterocolitica virulence genes as presented in Table (8) and Fig. (4), previous study conducted by Shabana (2015) reported detection of ystA gene in $Y$. enterocolitica strains isolated from raw chicken meat cut samples.

Compliance of the present results, with the previous reports proved that fresh chicken meat and giblet still have been exposed to several food poisoning bacterial sources; in addition, PCR is a good and reliable confirmatory diagnostic assay for virulence bacteria.

\section{CONCLUSION}

From the present results, it was concluded that polymerase chain reaction (PCR) can be useful, rapid, and confirmatory detector of a single copy virulence genes of pathogenic bacteria in chicken meat and giblet, and thus, it is recommended to be used to detect pathogenic bacterium in food rapidly.

\section{CONFLICT OF INTEREST}

No conflicts of interest

\section{REFERENCES}

1. Appleford, M.R., Oh S., Oh N., Ong J.L., 2009. In vivo study Abd El-Halim, M.O. 2017. Public health importance of salmonellosis in Qualyobia province. Thesis, Master of Veterinary Medicine (Zoonosis), Benha University, Egypt.

2. Abd El-Salam, S.R. 2018. Staphylococcus aureus in broiler carcasses. Thesis, Master of Veterinary Medicine (Meat Hygiene), Benha University, Egypt.

3. Abdallah, R.R.M. 2018. Rapid detection of food borne pathogens in different food stuffs". Thesis, Master of Veterinary Medicine (Microbiology), Cairo University, Egypt. 
4. Ahmed, Z.A. 2016. Detection of toxigenic Staphylococcus aureus in locally slaughtered chicken and beef in Luxor city by using of multiplex PCR. Thesis, Ph.D. of Veterinary Medicine (Meat Hygiene), South Valley Univ., Egypt.

5. Baumler, A.J., Tsolis, R.M., Heffron, F. 2000. Virulence mechanisms of Salmonella and their genetic basis. In: Salmonella in domestic animals. eds Wray, C., Wray, A. Wallingford, Oxford Shire, UK, CAB International, pp. 5769.

6. Bhandari, N., Nepali, D.B., Paudyal, S. 2013. Assessment of bacterial load in broiler chicken meat from the retail meat shops in Chitwan, Nepal. International Journal of Infection and Microbiology, 2(3): 99-104.

7. Bolton, D. J., Ivory, C. and McDowell, D. 2013. A small study of $Y$. enterocolitica in pigs from birth to carcass and characterization of porcine and human strains". Food Control, 33(2): 521-524

8. Capita, R., Alonso, C., Fernandez, M.D., Moreno, B. 2004. Microbiological quality of retail poultry carcasses in Spain. J. Food Protection, 64(12): 1961-1966.

9. CDC "Centers for Disease Control and Prevention" (2016) Information on this website focuses on Yersinia enterocolitica, which causes yersiniosis. https://www. cdc.gov/yersinia/. Accessed 10/3/2020

10. CDC "Centers for Disease Control and Prevention" (2019): Yersinia enterocolitica (Yersiniosis): Questions and Answers. https://www.cdc.gov/yersinia/faq.html

11. CDC "Centers for Disease Control and Prevention" (2020) Salmonella. https://www.cdc.gov/salmonella/. Accessed $10 / 3 / 2020$

12. Collins, C.H., Lyne, P.M., Grange, J.M. 1991 Microbiological methods. Butter Worth, London, Boston, Toronto.

13. Dhanashree, B. and Mallya, S. 2008. Detection of shigatoxigenic Escherichia coli (STEC) in diarrhoeagenic stool and meat samples in Mangalore, India. Indian J. Medical Research, 128: 271-277.

14. Duncan, M.J., Mann, E.L., Cohen, M.S., Ofek, I., Sharon, N., Abraham, S.N. 2005. The distinct binding specificities exhibited by enterobacterial Type 1 - Fimbriae are determined by their fimbrial shafts. J. Biology and Chemistry, 280: 37707-37716.

15. Eissa, M.O. 2017. Molecular characterization of Salmonella species isolated from some meat products. Thesis, Master of Veterinary Medicine (Bacteriology, Mycology and Immunology), Kafr Elsheikh University, Egypt.

16. El-Hanafy, A.R.A. 2019. Virulence factors associated with food poisoning bacteria in some beef and chicken meat products. Thesis, Master of Veterinary Medicine (Meat Hygiene), Benha University, Egypt.

17. Fagan, P., Hornitzky, M., Bettelheim, K., Djordjevic, S. 1999. Detection of Shiga-like toxin (STX1 and STX2), Intimin (eaeA), and Enterohemorrhagic Escherichia coli (EHEC) Hemolysin (EHEC hlyA) genes in animal feces by multiplex PCR. Applied Environmental Microbiology, 65(2): 868-872.

18. Fratamico, P., Sackitey, S., Wiedmann, M., Deng, M. 1995 Detection of Escherichia coli $\mathrm{O}_{157}: \mathrm{H}_{7}$ by multiplex PCR. J. Clinical Microbiology, 33: 2188- 2191.

19. Gaafar, H.W. 2018. Demonstration of Staph. aureus in some meat products using PCR technique". Thesis, Master of Veterinary Medicine (Meat Hygiene), Benha University, Egypt.

20. Galan, J.E., Ginocchio, C., Costeas, P. 1992. Molecular and functional characterization of the Salmonella invasion gene invA: homology of invA to members of a new protein family. J. Bacteriology, 174: 4338-4349.

21. Gomez-Duarte, O.G., Romero-Herazo, Y.C., Paez-Canro, C.Z., Eslava-Schmalbach, J.H., Arzuza, O. 2013 Enterotoxigenic Escherichia coli associated with childhood diarrhoea in Colombia, South America Journal of infection in developing countries, 7(5): 372-381.

22. Guo X., Chen J., Beuchat, L., Brackett, R. 2000. PCR detection of Salmonella enterica serotype Montevideo in and on raw tomatoes using primers derived from hilA. Applied Environmental Microbiology, 66: 5248-5252.
23. Hassan, Z.H. 2012. Conventional and rapid detection of Escherichia coli and Staphylococcus aureus in some meat products. Thesis, Ph.D. of Veterinary Medicine (Meat hygiene), Menoufiya University (Sadat branch).

24. Heiman, K.E., Mody, R.K., Johnson, S.D., Griffin, P.M. Gould, L.H. 2015. Escherichia coli $\mathrm{O}_{157}$ outbreaks in the United States, 2003-2012. Emerged Infectious Diseases, 21(8): 1293-1301.

25. Ibrahim, A., Liesack, M., Griffiths, A., Robins-Browne, R. 1997. Development of a highly specific assay for rapid identification of pathogenic strains of Yersinia enterocolitica based on PCR amplification of the Yersinia heat-stable enterotoxin gene (yst). J. Clinical Microbiology, 35:16361638.

26. ISO "International Organization for Standardization" 10273:2017. Microbiology of the food chain - Horizontal method for the detection of pathogenic Yersinia enterocolitica.

27. ISO "International Organization for Standardization" 16649 2: 2001. Microbiology of food and animal feeding stuffs Horizontal method for the enumeration of glucuronidasepositive Escherichia coli - Part 2: Colony-count technique at $44{ }^{\circ} \mathrm{C}$ using 5-bromo-4-chloro-3-indolyl-D-glucuronide.

28. ISO "International Organization for Standardization" 6579 1:2017. Microbiology of the food chain Horizontal method for the detection, enumeration and serotyping of Salmonella Part1: Detection of Salmonella spp.

29. ISO "International Organization for Standardization" 6888 1:1999, A1:2003. Microbiology of food and animal feeding stuffs-Horizontal method for the enumeration of coagulasepositive staphylococci (Staphylococcus aureus and other species) - Part 1: Technique using Baird-Parker agar medium (includes amendment A1:2003).

30. Jørgensen, H.J., Mathisen, T., Lovseth, A., Omoe, K., Qvale, K.S., Loncarevic, S. 2005. An outbreak of staphylococcal food poisoning caused by enterotoxin $\mathrm{H}$ in mashed potato made with raw milk. FEMS. Microbiol. Lett., 252(2): 267-272.

31. Kaper, J.B., Nataro, J.P., Mobely, H.L.T. 2004. Pathogenic E. coli. National Reviews Microbiology, 2(2): 123-140.

32. Kauffman, G. 1974. Kauffman white scheme. WHO, BD 172 L. Rev. 1. Acta Pathologica et Microbiologica Scandinavica, 61: 385 .

33. Kok, T., Worswich, D., Gowans, E. 1996. Some serological techniques for microbial and viral infections. In: Practical Medical Microbiology, Collee, J., Fraser, A., Marmion, B. and Simmons, A. (Eds.), 14 ${ }^{\text {th }}$ Ed., Edinburgh, Churchill Livingstone, UK.

34. Majowicz, S.E., Musto, J., Scallan, E., Angulo, F.J., Kirk, M., O'Brien, S.J., Jones, T.F., Fazil, A., Hoekstra, R.M. 2010. The global burden of non-typhoidal Salmonella gastroenteritis. Clinical Infectious Diesases, 50: 882-889.

35. Mazaheri, S., Ahrabi, S., Aslani, M. 2014. Shiga toxinproducing Escherichia coli isolated from lettuce samples in Tehran, Iran. Jundishapur J. Microbiology, 7(11): 1-6.

36. Mehrotra, M., Wang, G., Johnson, W. 2000. Multiplex PCR for detection of genes for Staphylococcus aureus enterotoxins, exfoliative toxins, toxic shock syndrome toxin 1, and methicillin resistance. J. Clinical Microbiology, 38: 10321035.

37. Menghistu, H. 2010. Studies on molecular heterogeneity among Salmonella gallinarum isolates of poultry origin. Thesis, Master of Veterinary Medicine, Deemed Univ., IVRI, Izatnagar, Bareilly.

38. Mohamed, M.A.K. 2017. Challenge of multi drug-resistant STX1 harboring E. coli in meat and fast foods. Thesis, Master of Veterinary Medicine (Meat Hygiene), Benha University, Egypt.

39. Momtaz, H., Rahimian, M., Dehkordi, F. 2013. Identification and characterization of Yersinia enterocolitica isolated from raw chicken meat based on molecular and biological techniques. J. Applied Poultry Researches, 22: 137-145.

40. Mustafa, N.F. 2018. Studies on virulence genes of E. coli strains isolated from chickens intended for human consumption". Thesis, Master of Veterinary Medicine (Bacteriology, Mycology and Immunology), Mansoura University, Egypt. 
41. Naguib, R.A. 2017. Detection of virulent genes responsible for Staphylococcus aureus enterotoxins production in chicken meat using PCR. Thesis, Ph.D. of Veterinary Medicine (Meat Hygiene), Benha Univ., Egypt.

42. Normanno, G., La Salandra, G., Dambrosio, A., Quaglia N.C., Corrente, M., Parisi, A., Santagada, G., Firin, U.A., Crisetti, E., Celano, G.V. 2007. Occurrence, characterization and antimicrobial resistance of enterotoxigenic Staphylococcus aureus isolated from meat and dairy products. International J. Food Microbiology, 115: 290-296.

43. Paton, A.W., Paton J.C. 1998. Detection and characterization of shiga toxigenic Escherichia coli by using multiplex PCR assays for STX 1, STX 2, eaeA, Enterohemorrhagic E. coli $h l y A, r f b \mathrm{O}_{111}$ and $r f b \mathrm{O}_{157}$. J. Clinical Microbiolpgy, 36: 598602.

44. Rall, V., Vieira, F., Rall, R., Vieitis, R., Fernandes, A., Candeias, J., Cardoso, K., Araujo, J. 2008. PCR detection of staphylococcal enterotoxin genes in Staphylococcus aureus strains isolated from raw and pasteurized milk. Vet. Microbiology, 132: 408-413.

45. Rasmussen, H., Rasmussen, O., Andersen, J., Olsen, J. 1994. Specific and detection of pathogenic Yersinia enterocolitica by two-step PCR using hot-start DMSO. Mol. Cell. Probes 8: 99-108.

46. Sami, M., Roya F. 2007. Prevalence of Escherichia coli $\mathrm{O}_{157}: \mathrm{H}_{7}$ on dairy farms in Shiraz, Iran by immunomagnetic separation and multiplex PCR. Iran J. Veterinary Researches, 4: 319-324.

47. Shabana, S.M. 2015. Identification and molecular analysis of Yersinia enterocolitica isolated from chicken meat samples". Thesis, Master of Veterinary Medicine (Microbiology), Alexandria University, Egypt.

48. Shah, D., Shringi, S., Besser, T., Call, D. 2009. Molecular detection of foodborne pathogens, Boca Raton: CRC Press, In
Liu, D. (Ed). Taylor \& Francis group, Florida, USA, Pp. 369389.

49. Shanmugasamy, M., Velayutham, T., Rajeswar, J. 2011. Inv A gene specific PCR for detection of Salmonella from broilers. Vet. World, 4 (12): 562-564.

50. Shedeed, N.A. 1999. Evaluation of microwave cooking of chicken meat. Thesis, Master of Agriculture, Cairo University.

51. Singh, S., Singh, H., Tewari, S., Prejit, N., Agarwal, R. 2013 Characterization of virulence factors among diverse Salmonella serotypes and sources. Advanced Animal Veterinary Science, 1(2): 69-74.

52. Sodha, S.V., Griffin, P.M., Hughs, J.M. 2009. Food born disease. In: Mandell GL, Bennett, JE, Dolin, R. (eds). Principles and practice of Infectious Disease $.7^{\text {th }}$ Ed., philadelphia, Elsevier Churchill Livingstone: Chap. 99, staphylococci: implications for our food supply. Anim. Health Res. Rev., 13: 157-180.

53. Synge, B.A. 2000. Verotoxin producing E. coli: A veterinary view. J. applied Microbiology, 88: 315-375.

54. Wang, L., Li, Y., Mustapha, A. 2007. Rapid and simultaneous quantification of Escherichia coli $\mathrm{O}_{157}: \mathrm{H}_{7}$, Salmonella and Shigella in ground beef by multiplex real-time PCR and immune-magnetic separation. J. Food Protection., 70(6): 1366-1372.

55. Ziprin, R.L., Hume, M.E. 2001. Human Salmonellosis: general medical aspects. In: Y.H. Hui, M.D. Pierson, and J.R. Gorham (eds.), Food borne Disease Handbook, $1^{\text {st }}$ Ed., Bacterial Pathogens, Marcel Dekker, Inc., New York, NY. Pp. 285-321.

56. Živković, J. 2001. Meat hygiene and Technology. Veterinary and Sanitary Supervision of Animals for Slaughter and Meat. Part I. $2^{\text {nd }}$ edition. M. Hadžiosmanović (Ed.). Faculty of Veterinary Medicine, University of Zagreb. 